\title{
Urgensi DSN-MUI sebagai Otoritas Pengawas Syariah Lembaga Keuangan Syariah
}

\author{
Marlisa Elpira \\ Pengadilan Agama Sungai Raya \\ Email:marlisaelvira615@gmail.com \\ Marli Candra \\ UIN Sunan Ampel Surabaya \\ Email:mcand23@uinsby.ac.id
}

\begin{abstract}
The existence of a sektoral supervisory system in the financial service sektors may lead to disagreements in solving financial problems, which resulting in inefficiency of the supervision. The ideal Islamic financial institution Supervision system is not only in the operational institution aspect, but also includes oversight of compliance to apply the Islamic Principles in all of financial activities, which should be an integral part of the Financial Services Authority (OJK). By using the normative legal research with secondary data were analyzed qualitatively, the author conclude that the position of DSN-MUI as an separated institution from the OJK have some weaknesses: disagreement between the agency authority to DSN-MUI in understanding Islamic financial problems, there are some fatwas can not be absorbed in legislations language, the violations of Islamic principles, DPS are being bound to the bank because of salary, and the not-binding DSN-MUI fatwas to Islamic Banks directly. Therefor, the presence of OJK as an institution Financial services authority must be equipped with a compotent shariah supervisory structure.
\end{abstract}

Key Words: sektoral supervisory system; Islamic principles; the financial services authority.

\begin{abstract}
Abstrak: Adanya sistem pengawasan sektoral di sektor jasa keuangan dapat menyebabkan ketidaksepahaman dalam memecahkan masalah keuangan yang terjadi, yang berakibat kepada ketidakefisienan pengawasan tersebut. Sistem pengawasan lembaga keuangan syariah yang ideal adalah mengawasi kegiatan operasional lembaga keuangan secara umum sekaligus mengawasi kepatuhan menerapkan prinsip Syariah dalam kegiatan tersebut, di mana keduanya harus menjadi satu kesatuan yang tidak terpisahkan dalam otoritas jasa keuangan yang Islami. Dengan menggunakan metode penelitian hukum normatif yang menggunakan data sekunder yang dianalisis secara kualitatif, penulis menyimpulkan bahwa kedudukan DSN-MUI sebagai lembaga yang terlepas dari lembaga otoritas di sektor jasa keuangan memiliki beberapa kelemahan: ketidaksepahaman antara lembaga otoritas dengan DSN dalam memahami masalah di sektor jasa keuangan
\end{abstract}


syariah, terdapat fatwa yang tidak dapat diserap dalam bahasa peraturan perundang-undangan, adanya pelanggaran prinsip syariah, terikatnya DPS dengan bank yang diawasi dengan adanya biaya transportasi yang menjadi beban bank syariah terkait, serta tidak mengikatnya fatwa DSN secara langsung terhadap bank-bank syariah. Oleh karena itu, kehadiran OJK sebagai lembaga otoritas jasa keuangan harus dilengkapi dengan struktur pengawasan syariah yang kompeten.

Kata Kunci: Sistem pengawasan sektoral; Prinsip-prinsip Syariah; Otoritas Jasa Keuangan Syariah.

\section{PENDAHULUAN}

Bank merupakan lembaga keuangan yang mempunyai fungsi perantara (intermediation role), yaitu sebagai penyediaan kuasa untuk aliran dana dari mereka yang mempunyai dana yang tidak dimanfaatkan atau kelebihan dana selaku penabung (saver) dan pemberi pinjaman (lender) kepada mereka yang memerlukan atau kekurangan dana untuk memenuhi berbagai kepentingan selaku peminjam (borrower), ${ }^{1}$ serta meningkatkan taraf hidup rakyat. ${ }^{2}$ Dengan demikian, ada dua peranan penting yang dimainkan oleh bank yaitu sebagai lembaga penyimpan dana masyarakat dan sebagai lembaga penyedia dana bagi masyarakat dan atau dunia usaha.

Pengembangan sistem lembaga keuangan syariah di Indonesia dilakukan dalam kerangka dual-banking system atau sistem lembaga keuangan ganda dalam kerangka Arsitektur Lembaga keuangan Indonesia (API), untuk menghadirkan alternatif jasa lembaga keuangan yang semakin lengkap kepada masyarakat Indonesia. Secara bersama-sama, sistem lembaga keuangan syariah dan lembaga keuangan konvensional secara sinergis mendukung mobilisasi dana masyarakat secara lebih luas untuk meningkatkan kemampuan pembiayaan bagi sektor-sektor perekonomian nasional. Dua dari enam pilar kerangka API ini adalah pengaturan lembaga keuangan yang efektif dengan bertujuan untuk meningkatkan efektivitas pengaturan serta memenuhi standar pengaturan yang mengacu pada international best practices. Program tersebut dapat dicapai dengan penyempurnaan proses penyusunan kebijakan lembaga keuangan serta penerapan 25 Basel Core Principles for Effective Banking Supervision secara bertahap dan menyeluruh. Serta pengawasan bank yang independen dan efektif untuk saat ini maupun jangka panjang sebagai jawaban atas meningkatnya kegiatan usaha maupun kompleksitas risiko yang dihadapi yang dihadapi lembaga keuangan. 3

Pada umumnya bank syariah memiliki produk-produk dalam jasa penghimpunan dan pembiayaan, khususnya berbagai jenis kontrak (akad) yang diatur sesuai syariah yang berfungsi memperlancar mekanisme ekonomi di

\footnotetext{
1 Syukri Iska, Sistem Perbankan Syariah di Indonesia Dalam Perspektif Fikih Ekonomi, (Yogyakarta: Fajar Media Press, 2012), 20.

2 Seperti tercantum dalam Pasal 1 UU No. 10 Tahun 1998 tentang Perbankan dan Pasal 1 ayat (2) UU No. 21 Tahun 2008 tentang Perbankan Syariah.

3 BI, Arsitektur Perbankan Indonesia dalam http://www.bi.go.id/web/id/ pada 10/30/2013 $1: 48 \mathrm{am}$.
} 
sektor riil melalui aktivitas kegiatan usaha (investasi, jual beli, atau lainnya) berdasarkan prinsip syariah, baik yang bersifat makro maupun mikro. ${ }^{4}$ Dimensi keberhasilan bank syariah meliputi keberhasilan dunia dan akhirat (long term oriented) yang sangat memerhatikan keberhasilan sumber, kebenaran proses, dan kemanfaatan hasil. Bank syariah sebagai suatu institusi jasa keuangan diatur5 dan diawasi 6 oleh lembaga otoritas yang sama yang juga mengawasi bank-bank konvensional.

Pengaturan dan pengawasan terhadap lembaga keuangan syariah tidak hanya bertujuan untuk meningkatkan keyakinan setiap orang yang mempunyai kepentingan dengan bank, bahwa bank-bank dari segi financial tergolong sehat, dikelola dengan baik dan professional, serta tidak terdapat hal-hal yang dapat mengancam kepentingan masyarakat yang menyimpan dananya di bank,7 tetapi juga terjaminnya produk lembaga keuangan yang terhindar dari unsur-unsur yang dilarang menurut agama Islam (syariah). Dalam Pasal 1 angka 12 UU No 21 Tahun 2008 tentang Perbankan syariah dikatakan bahwa prinsip syariah adalah prinsip hukum Islam dalam kegiatan lembaga keuangan berdasarkan fatwa yang dikeluarkan oleh lembaga yang memiliki kewenangan dalam penetapan fatwa di bidang syariah. ${ }^{8}$ Kemudian dalam Penjelasan Pasal 2 disebutkan bahwa kegiatan usaha yang berdasarkan prinsip syariah antara lain, adalah kegiatan usaha yang tidak mengandung unsur: riba, maisir, gharar, haram, dan zalim. Unsur-unsur terlarang tersebut, pada prinsipnya tidak bisa didefinisikan dengan kacamata peraturan perundang-undangan dan/atau BI/OJK. Maka timbul persoalan institusi regulator yang mempunyai otoritas mengatur dan mengawasi lembaga keuangan syariah tersebut tidak dapat melaksanakan otoritasnya dibidang syariah karena tidak memiliki otoritas untuk merumuskan prinsip-prinsip syariah secara langsung dari teks-teks

\footnotetext{
4 Nilai-nilai makro tersebut adalah keadilan, maslahah, sistem zakat, bebas bunga (riba), bebas dari kegiatan-kegiatan spekulatif yang nonproduktif, bebas dari hal-hal yang tidak jelas, rusak, tidak sah (batil), dan penggunaan uang sebagai alat tukar dan bukan komoditi. Sedangakan nilai-nilai mikro adalah sifat-sifat yang dicontohkan oleh Rasulullah saw seperti: shiddiq, amanah, tabligh, dan fathana Ascarya, Akad dan Produk Bank Syariah, (Jakarta: Rajawali Press, 2013), 30.

5 Pengaturan perbankan pada umumnya terdiri atas pemberian izin, dalam menjalankan kegiatan usaha, kepengurusan, dan sebagainya. Lihat UU No. 7 Tahun 1992 jo. UU No. 10 Tahun 1998 tentang Perbankan dan UU No. 21 tahun 2998 tentang Perbankan Syariah.

6 Pengawasan bank dilakukan dengan menggunakan dua pendekatan: (1) Pengawasan berdasarkan kepatuhan (compliance based supervisor), yaitu pemantauan yang terkait dengan operasi dan pengelolaan bank di masa lalu dengan tujuan memastikan bahwa bank telah beroperasi dan dikelola secara baik dan benar menurut prinsip-prinsip kehati-hatian; (2) Pengawasan terhadap pemenuhan aspek kepatuhan merupakan bagian tidak terpisahkan dari pelaksanaan pengawasan bank berdasarkan risiko Pengawasan berdasarkan risiko (risk based supervisor), yaitu pengawasan bank yang menggunakan strategi dan metodologi berdasarkan risiko yang memungkinkan pengawas bank dapat mendeteksi risiko yang signifikan secara dini dan mengambil tindakan pengawasan yang sesuai dan tepat waktu. Meliputi risiko kredit, risiko pasar, risiko likuiditas, risiko operasional, risiko hukum, risiko reputasi, risiko strategic, dan risiko kepatuhan. Departemen Perizinan dan Informasi Perbankan, Booklet Perbankan Indonesia 2013, (Jakarta: BI, 2013), 20.

7 Hermansyah, Hukum Perbankan Nasional Indonesia, (Jakarta: Kencana Prenada Media Grup, 2011), 173 .

8 Ketentuan tersebut juga diatur dalam Pasal 26 UU Perbankan Syariah.
} 
keagamaan dalam bentuk peraturan (regulasi) yang bersesuaian untuk setiap lembaga keuangan syariah. Maka peran DSN-MUI sebagai otoritas syariah di Indonesia sangat dibutuhkan dalam perkembangan lembaga keuangan syariah di Indonesia.

Dalam sektor riil, bank sangat bergantung kepada kepercayaan dari masyarakat. Apabila masyarakat percaya pada bank, maka masyarakat akan merasa aman untuk menyimpan uang atau dananya di bank. Bank harus selalu menjaga tingkat kepercayaan dari nasabah sehingga masyarakat akan menyimpan dana mereka di bank, dan bank dapat menyalurkan dana tersebut untuk menggerakkan perekonomian bangsa. Kepercayaan tersebut timbul dari adanya perlindungan atas hak-hak, kepentingan dan kehendak nasabah sebagai pengguna jasa keuangan yang dioperasikan pihak bank. Sehingga tidak mengherankan bahwa dunia jasa keuangan harus sedemikian rupa menjaga kepercayaan dari masyarakat dan memberikan perlindungan hukum terhadap kepentingan masyarakat, terutama kepentingan nasabah dari bank bersangkutan. 9 Salah satu unsur penting dalam melindungi kepentingan nasabah tersebut adalah tingkat kepatuhan bank.

Ukuran untuk tingkat kepatuhan bank syariah tidak hanya dengan mengacu pada ketentuan-kententuan umum yang telah ditetapkan oleh lembaga otoritas, tetapi juga patuh dalam arti menjaga dan memelihara prinsipprinsip syariah yang menjadi ciri khas dan karakteristik lembaga keuangan syariah, sebagaimana diatur dalam UU No. 21 Tahun 2008 tentang Lembaga keuangan Syariah Pasal 2 yang berbunyi: Lembagakeuangan syariah dalam melakukan kegiatan usahanya berasaskan prinsip syariah, demokkrasi ekonomi, dan prinsip kehati-hatian. Ketentuan ini memberikan pengertian bahwa bank syariah dalam melaksanakan aktivitas keuangannya, harus berdasarkan prinsip syariah, di mana tingkat kepatuhannya tidak hanya atas pertimbangan BI, melainkan juga dengan pertimbangan DSN-MUI dan DPS yang dibentuk pada masing-masing bank syariah. ${ }^{10}$ Tingkat kepatuhan bank syariah ini diperjelas dengan PBI No. 13/2/PBI/2-11 tentang Pelaksanaan Fungsi Kepatuhan Bank Umum Pasal 1 ayat (5) dan (6) yang berbunyi:

Budaya kepatuhan adalah nilai, perilaku, dan tindakan yang mendukung terciptanya kepatuhan terhadap ketentuan BI dan peraturan perundang-undangan yang berlaku, termasuk prinsip syariah bagi bank umum syariah dan unit usaha syariah.

Fungsi Kepatuhan adalah serangkaian tindakan atau langkah-langkah yang bersifat ex-ante (preventif) untuk memastikan bahwa kebijakan, ketentuan, sistem, dan prosedur, serta kegiatan usaha yang dilakukan oleh Bank telah sesuai dengan ketentuan Bank Indonesia dan peraturan perundangundangan yang berlaku, termasuk Prinsip Syariah bagi Bank Umum Syariah dan Unit Usaha Syariah, serta memastikan kepatuhan Bank terhadap komitmen yang dibuat oleh Bank

\footnotetext{
9 Hermansyah, 144 .

${ }^{10}$ Sebagaimana diatur dalam Penjelasan Umum UU Perbankan Syariah. 


\section{kepada Bank Indonesia dan/atau otoritas pengawas lain yang}

berwenang.

Akan tetapi, mengingat DSN-MUI adalah lembaga swasta yang tidak memiliki otoritas penuh dalam penentuan kebijakan negara terhadap perkembangan lembaga keuangan syariah (LKS), sehingga perlu ada kajian tentang kedudukan DSN-MUI dikaitkan dengan keberadaan OJK sebagai lembaga otoritas pengatur dan pengawas seluruh kegiatan keuangan syariah yang dilakukan oleh LKS. Hasil penelitian ini diharapkan dapat memperkaya khazanah ilmu pengetahuan, khususnya di bidang ekonomi dan menjadi bahan rujukan dalam memperbaiki sistem pengaturan dan pengawasan LKS di Indonesia.

\section{METODE PENELITIAN}

Penelitian ini merupakan penelitian hukum yang berbentuk penelitian yuridis-normatif yang menitikberatkan pada penggunaan norma-norma hukum secara tertulis serta didukung pada studi kepustakaan untuk mendapatkan data utamanya, serta hasil wawancara dengan narasumber apabila diperlukan sebagai data pelengkap dalam melakukan analisis terhadap permasalahan dalam penelitian ini. ${ }^{11}$ Di sini peneliti menganalisis tentang masalah terkait tingkat kepatuhan bank syariah dan kedudukan DSN-MUI dalam penentuan kepatuhan tersebut. Dalam penelitian ini, jenis data yang digunakan adalah data sekunder, dengan:12

a. Bahan hukum primer, yaitu bahan hukum yang bersifat mengikat dan digunakan untuk mendapatkan dasar hukum dalam penelitian ini, yaitu peraturan perundang-undangan yang berkaitan dengan kedudukan DSN-MUI dalam pengaturan dan pengawasan lembaga keuangan syariah, yaitu:

1) Undang-Undang No. 21 Tahun 2008 tentang Lembaga keuangan Syariah

2) UU No 21 Tahun 2011 tentang Otoritas Jasa keuangan

3) PBI No. 13/2/PBI/2-11 tentang Pelaksanaan Fungsi Kepatuhan Bank Umum

b. Bahan hukum sekunder yaitu bahan hukum yang digunakan untuk mendapatkan penjelasan maupun pendapat para ahli hukum terhadap bahan hukum primer, yang diperoleh melalui studi kepustakaan, termasuk di dalamnya Kumpulan Fatwa DSN-MUI.

Data yang telah diperoleh tersebut kemudian dianalisis secara kualitatif untuk menemukan jawaban dari permasalahan yang diteliti sehingga dapat ditarik suatu kesimpulan yang dikaitkan dengan teori-teori dan konsep yang relevan dengan permasalahan tersebut.

${ }^{11}$ Zainuddin Ali, Metode Penelitian Hukum, (Jakarta: Sinar grafika, 2011), 24.

12 Soerjono Soekanto dan Sri Mamudji, Penelitian Hukum Normatif, (Jakarta: Raja Grafindo Persada, 2007), 29-33. 


\section{PEMBAHASAN}

\section{Lembaga Otoritas Jasa Keuangan Syariah}

Pengaturan dan pengawasan jasa keuangan suatu Negara pada umumnya dilakukan oleh bank sentral. Akan tetapi sejalan dengan semakin kompleks dan dinamisnya sistem jasa keuangan, sebagian Negara lakukan inovasi baru dalam hal pengaturan dan pengawasan jasa keuangan dengan membentuk lembaga independen yang terpisah dari bank sentral, yang disebut dengan Financial Services Authority (FSA) seperti Negara-negara Eropa seperti Inggris, Belanda, Amerika Serikat, Belgia, Irlandia, Austria, Finlandia, serta Negara-negara lain seperti Jepang, Korea Selatan, Kazakhstan, Nikaragua,13 dan termasuk juga Indonesia dengan ditetapkannya UU OJK Tahun 2011 lalu.14 Model/sistem pengawasan yang terpisah dari bank sentral ini diterapkan secara resmi pertama kali oleh Inggris dan diikuti oleh Negara-negara Eropa lainnya.

Seperti yang kita ketahui bahwa model FSA ini berkembang dan di Eropa yang notabennya hanya mengenal sistem keuangan konvensional (liberal). Sedangkan Negara negara yang mengembangkan dual banking system sistem pengawasan lembaga keuangan (konvensinal maupun syariah) tetap berada di bawah wewenang bank sentral, di mana bank sentral memiliki direksi/dewan syariah yang khusus mengawasi jasa keuangan syariah, di samping dewan Syariah yang ada di tiap-tiap bank syariah. ${ }^{15} \mathrm{Hal}$ inilah yang menjadi tantangan bagi OJK sebagai lembaga otoritas dalam mengembangkan sistem keuangan syariah di tanah air.

\section{a. DSN-MUI Sebagai Lembaga Otoritas Syariah Independen}

DSN-MUI adalah lembaga otonom di bawah MUI yang berfungsi mengawasi produk-produk lembaga keuangan syariah agar sesuai dengan syariah Islam. DSN dibentuk tahun 1997 dan merupakan hasil rekomendasi Lokakarya Reksada Syariah, dengan pimpinan Ketua MUI dan sekretaris (exofficio)di mana kegiatan sehari-hari DSN dijalankan oleh Badan Pelaksanan

\footnotetext{
13 Donato Masciandaro dan Marc Quintyn, "Reforming Financial Supervision and the Role of Central Banks: a Review of Global Trends, Causes and Effects (1998-2008)," Centre of Economic Policy Research, Februari 2009, 1.

14 Pada awalnya pengaturan dan pengawasan bank adalah tugas dan wewenang BI sebagai bank sentral. Akan tetapi karena adanya proses globalisasi sistem keuangan yang bertambah kompleks dan dinamis, serta banyak terjadi juga permasalahan lintas sektoral di sektor jasa keuangan, moral hazard, serta lemahnya perlindungan konsumen jasa keuangan, Pemerintah mengupayakan terbentuknya kerangka peraturan dan pengawasan sektor jasa keuangan yang terintegrasi dan komprehensif, maka wewenang BI dalam pengaturan dan pengawasan terhadap Perbankan beralih ke OJK, persisnya berdasarkan Pasal 55 ayat (2) UU OJK, OJK secara mutlak akan melaksanakan tugasnya dalam mengatur dan mengawasi perbankan pada awal tahun 2014. Kebijakan Pemerintah tersebut bertujuan dalam rangka mewujudkan perekonomian nasional yang mampu tumbuh stabil dan berkelanjutan dan memberikan kesejahteraan secara adil kepada seluruh rakyat Indonesia dan dilaksanakan secara komprehensif dan mampu menggerakkan kegiatan perekonomian Nasional sesuai UUD 1945 (Penjelasan Pasal 4).

${ }_{15}$ Negara-negara tersebut adalah Afganistan, Malaysia, Pakistan, Palestina, Sudan, dan Syiria, Inwong Song dan Carel Oosthuizen, "Islamic Banking Regulation and Supervision: Survey Result and Challenges," IMF Paper, Desember 2014, 16-17.
} 
Harian dengan seorang ketua dan sekretaris serta beberapa anggota. ${ }^{16}$ Tugas utama DSN adalah menumbuh-kembangkan penerapan prinsip syariah, mengeluarkan fatwa yang berhubungan dengan jenis-jenis kegiatan, produk, dan jasa keuangan, ${ }^{17}$ Lebih dari itu, DSN juga bertugas mengembangkan dan mengawasi terlaksananya fatwa dalam produk keuangan syariah. Hal tersebut bertujuan untuk memberi kepastian dan jaminan hukum Islam dalam masalah keuangan syariah setelah mendapat peluang operasi sejak diberlakukannya UU No. 7 Tahun 1992 tentang Lembaga keuangan ${ }^{18}$ dan berkembang pesat setelah terjadinya krisis moneter tahun 1997-1998 dan diubahnya UU ini dengan UU No. 10 Tahun 1998. ${ }^{19}$ Wewenang dan tugas DSN-MUI selanjutnya diperkuat dengan UU Perbankan Syariah, di mana DSN-MUI ditetapkan sebagai lembaga yang berwenang memberi ketentuan tentang standarisasi prinsip syariah di sektor jasa keuangan syariah.

Keberadaan DSN-MUI beserta produk hukumnya juga mendapat legitimasi dari BI yang tertuang dalam Surat Keputusan Direksi BI No. 32/34/1999, di mana pada pasal 31 dinyatakan: "untuk melaksanakan kegiatan-kegiatan usahanya, bank umum syariah diwajibkan memperhatikan fatwa DSN-MUI", lebih lanjut, dalam Surat Keputusan tersebut juga dinyatakan: "demikian pula dalam hal bank akan melakukan kegiatan sebagaimana dimaksudkan dalam Pasal 28 dan Pasal 29, jika ternyata kegiata usaha yang dimaksudkan belum difatwakan oleh DSN, maka wajib meminta persetujuan DSN sebelum melakukan usaha kegiatan tersebut”.

Untuk menjamin bahwa operasional lembaga keuangan syariah sesuai dengan prinsip syariah dan membantu tugas DSN-MUI, maka di setiap lembaga keuangan syariah wajib memiliki Dewan Pengawas Syariah (DPS) yang berfungsi sebagai perwakilan $\mathrm{DSN}^{20}$ yang disyaratkan terdiri dari orang-orang

\footnotetext{
${ }^{16}$ Muhammad Syafi'ie Antonio, Bank Syariah Dari Teori ke Praktik, (Jakarta: Gema Insani Press, 2007), 32.

${ }_{17}$ Dalam menerbitkan fatwa, DSN-MUI menggunakan empat sumber hukum yang disepakati (al Qur'an, Hadits, Ijma', dan Qiyas). Selain itu, digunakan juga salah satu sumber hukum yang diperselisihkan ulama (istihsan, maslahah mursalah, istishab, sad dzari'ah, 'urf, madzhab shahabi, dan sya'u man qablana) dengan prioritas madzhab Sunni yang empat dan mempertimbangkan madzhab lain yang bersifat fleksibel dan sesuai dengan keadaan yang berlaku. M. Cholil Nafis, Teori Hukum Ekonomi Syariah, (Jakarta: UI-Press, 2011), hal. 5. Lihat pula Keputusan DSN-MUI No. 1 Tahun 2000 tentang Pedoman Dasar Dewan Syariah Nasional Majelis Ulama Indonesia (PD DSN-MUI).

${ }^{18}$ M. Cholil Nafis, 5-6.

19 Pada era reformasi setelah terjadinya krisis moneter tahun 1997-1998, perkembangan perbankan syariah mendapat perhatian dari pemerintah sehingga ditetapkanlah UU. No. 10 Tahun 1998 yang berisi tentang landasan hukum dan jenis-jenis usaha yang dapat dioperasikan oleh bank syaria Muhammad Syafi'ie Antonio, 18-27.

${ }_{20}$ Peraturan Bank Indonesia Nomor 11/33/PBI/2009 tentang Pelaksanaan Good Corporate Governance Bagi Bank Umum Syariah dan Unit Usaha Syariah mempertegas lagi posisi Dewan Pengawas Syariah (DPS) bahwa setiap usaha Bank Umum yang membuka Unit Usaha Syariah diharuskan mengangkat DPS yang tugas utamanya adalah memberi nasehat dan saran kepada direksi serta mengawasi kesesuaian syaria Sedangkan dalam ketentuan UU Perbankan Syariah tegas dinyatakan bahwa DPS diangkat dalam rapat umum pemegang saham atas rekomendasi MUI.
} 
yang ahli syariah dan sedikit banyak menguasai hukum bisnis syariah, serta tidak terikat dengan lembaga yang diawasi. ${ }^{21}$ Tugas DPS adalah: ${ }^{22}$

a. Wajib mengikuti fatwa DSN

b. Merumuskan permasalahan yang memerlukan pengesahan DSN

c. Melaporkan kegiatan usaha serta perkembangan LKS yang diawasanya kepada DSN.

Dari uraian tersebut, maka dapat dikatakan bahwa DSN-MUI merupakan lembaga satu-satunya yang diberi amanat oleh undang-undang untuk menetapkan fatwa tentang ekonomi dan keuangan syariah, juga merupakan lembaga yang didirikan untuk memberikan ketentuan hukum Islam kepada lembaga keuangan syariah dalam menjalanan aktivitasnya. Ketentuan tersebut sangatlah penting dan menjadi dasar hukum utama dalam perjalanan operasinya. Tanpa adanya ketentuan hukum Islam, maka lembaga keuangan syariah akan kesulitan dalam menjalankan aktivitasnya. Sehingga DSN-MUI memiliki peran yang sangat penting dalam mengeluarkan fatwa-fatwa yang berkaitan dengan hukum muamalah maliyah (transaksi keuangan) untuk menjadi pedoman bagi para pelaku fiqh muamalah, khususnya dalam lembaga keuangan syariah.

\section{b. Hubungan DSN-MUI dengan OJK}

Pengaturan dan pengawasan lembaga keuangan Syariah merupakan salah satu tugas pokok dari Bank Indonesia. Dalam rangka pelaksanaan tugas pengaturan dan pengawasan bank, Bank Indonesia diberi wewenang untuk menetapkan peraturan dan perizinan bagi kelembagaan dan kegiatan usaha bank serta mengenakan sanksi terhadap bank sesuai peraturan perundangundangan yang berlaku. ${ }^{23}$ Bentuk kewenangan tersebut dituangkan secara operasional dengan dikeluarkan berbagai Peraturan Bank Indonesia (PBI) yang biasanya dilengkapi dengan Surat Edaran (SE) Bank Indonesia yang berfungsi sebagai petunjuk teknis pelaksanaan yang dapat dijadikan pedoman oleh bankbank di Indonesia.

Karena terjadinya proses globalisasi sistem keuangan yang bertambah kompleks dan dinamis, terjadinya banyak permasalahan lintas sektoral di sektor jasa keuangan, moral hazard, serta lemahnya perlindungan konsumen jasa keuangan, Pemerintah mengupayakan terbentuknya kerangka peraturan dan pengawasan sektor jasa keuangan yang terintegrasi dan komprehensif, ${ }^{24}$ maka wewenang BI dalam pengaturan dan pengawasan terhadap Lembaga keuangan beralih ke OJK, persisnya berdasarkan Pasal 55 ayat (2) UU OJK, OJK secara mutlak akan melaksanakan tugasnya dalam mengatur dan mengawasi lembaga keuangan pada awal tahun 2014. Kebijakan Pemerintah tersebut bertujuan dalam rangka mewujudkan perekonomian nasional yang mampu tumbuh stabil dan berkelanjutan dan memberikan kesejahteraan secara adil kepada seluruh rakyat Indonesia dan dilaksanakan secara komprehensif

${ }^{21}$ Warkum Sumitro, Asas-Asas Perbankan Syariah dan Lembaga-Lembaga Terkait, (Jakarta: Raja Grafindo Persada, 2004), 52.

22 M. Cholil Nafis, 99.

23 BAB VI Pasal 24 UU BI.

24 Hermansyah, 214. 
dan mampu menggerakkan kegiatan perekonomian Nasional sesuai UUD 1945. ${ }^{25}$ Berdasarkan Pasal 6 UU OJK, lembaga-lembaga yang akan berada di bawah pengawasan OJK adalah lembaga keuangan, pasar modal, perasuransian, dana pensiun, lembaga pembiayaan atau multifinance, dan lembaga jasa keuangan lainnya. Dengan lahirnya OJK maka peran serta BI sebagai pengatur dan pengawas lembaga keuangan berpindah ke OJK. ${ }^{26}$

Sebagaimana telah diuraikan sebelumnya bahwa kedudukan DSN-MUI dalam sektor jasa keuangan di Indonesia telah dijamin oleh peraturan perundang-undangan, khususnya UU Perbankan Syariah. Fatwa yang ditetapkan oleh DSN-MUI merupakan bahan dasar lembaga otoritas untuk menetapkan kebijakan di sektor jasa keuangan syariah. Sehingga dalam melakukan pengawasan pasar keuangan syariah, OJK selalu bersinergi dengan DSN-MUI ${ }^{27}$ dalam menetapkan kebijakan di sektor keuangan tersebut. Hal tersebut sejalan dengan amanat UU No. 21 Tahun 2008 tentang Lembaga keuangan Syariah yang menetapkan DSN-MUI sebagai lembaga yang berwenang memberi ketentuan tentang standarisasi prinsip syariah di sektor jasa keuangan syariah. Tugas utama DSN adalah menumbuh-kembangkan penerapan prinsip syariah, mengeluarkan fatwa yang berhubungan dengan jenis-jenis kegiatan, produk, dan jasa keuangan. ${ }^{28}$ Selain itu, DSN juga bertugas mengawasi produk-produk lembaga keuangan syariah agar sesuai dengan syariah Islam. ${ }^{29}$ Hal tersebut bertujuan untuk memberi kepastian dan jaminan hukum Islam dalam masalah keuangan syariah, khususnya lembaga keuangan syariah. $3^{\circ}$ Oleh karena itu, fatwa yang ditetapkan oleh DSN-MUI merupakan bahan dasar lembaga otoritas untuk menetapkan kebijakan di sektor jasa keuangan syariah. Hubungan OJK dengan DSN-MUI dapat dilihat dari bagan berikut:

\footnotetext{
25 Berdasarkan Penjelasan pasal 4 UU No. 21 Tahun 2011 tentang OJK. Selain pertimbanganpertimbangan sebagaimana terdapat dalam UU OJK, UU No 23 Tahun 1999 tentang BI juga mengamanatkan pembentukan lembaga pengawasan sektor jasa keuangan ini.

${ }^{26}$ Di mana berdasarkan UU BI (secara rinci dijelaskan pada Pasal 10 sampai dengan Pasal 25), sebagai Bank Sentral, BI bertujuan untuk mencapai dan memelihara kestabilan nilai rupiah dengan: (1) Menetapkan dan melaksanakan kebijakan moneter; (2) Mengatur dan mengawasi bank; (3) Mengatur dan menjaga kelancaran sistem pembayaran.

${ }_{27}$ DSN-MUI adalah lembaga otonom di bawah MUI yang berfungsi mengawasi produk-produk lembaga keuangan syariah agar sesuai dengan syariah Islam. Tugas utamanya adalah menumbuh kembangkan penerapan prinsip syariah, mengeluarkan fatwa yang berhubungan dengan jenis-jenis kegiatan, produk, dan jasa keuangan. Muhammad Syafi'ie Antonio, Op.Cit., 32.

${ }_{28}$ M. Cholil Nafis, 5 .

29 Muhammad Syafi'ie Antonio, 32.

${ }^{30}$ Berdasarkan UU tentang Perbankan Syariah Pasal 1 angka (12) UU No. 21 tahun 2008, DSNMUI ditetapkan sebagai lembaga yang berwenang memberi ketentuan tentang standarisasi prinsip syariah di sektor jasa keuangan syaria Yaitu: Prinsip syariah adalah prinsip hukum Islam dalam kegiatan perbankan berdasarkan fatwa yang dikeluarkan oleh lembaga yang memiliki kewenangan dalam penetapan fatwa dibidang syariah."
} 


\section{Gambar 3•3.2. OJK dan DSN-MUI Sinergy}

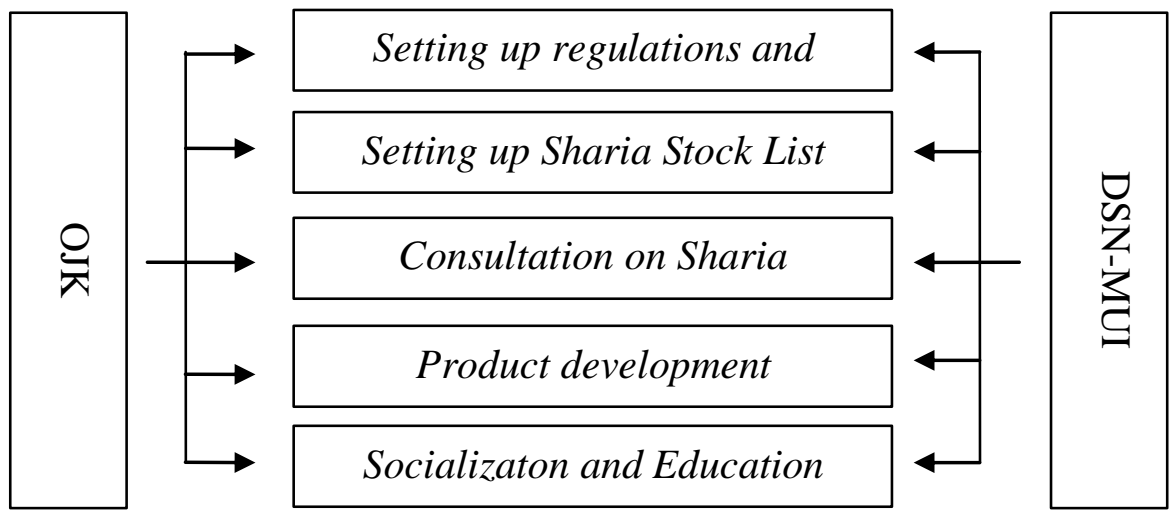

Sumber: Otoritas Jasa Keuangan 2014

Berdasarkan gambar di atas, DSN-MUI, sebelum memutuskan fatwa, terlebih dahulu mendengarkan keterangan dari OJK, sehingga keputusan fatwa yang ditetapkan sesuai dengan permasalahan yang ada, dan jika fatwa tersebut diakomodasi dalam peraturan (regulasi), maka akan tepat pada sasarannya. Juga sebaliknya, apabila OJK akan merumuskan kebijakan yang memerlukan informasi-informasi dalam aspek syariah, maka OJK akan mengundang DSNMUI untuk memberikan keterangan.

\section{c. Urgensi Terbentuknya Otoritas Syariah yang Kompeten}

Setelah ditetapkannya UU Perbankan Syariah, Lembaga keuangan mendapatkan dasar hukum yang kuat bagi operasional lembaga keuangan syariah dan memperkenalkan beberapa ketentuan hukum baru yang ditujukan untuk meningkatkan kepatuhan bank terhadap prinsip syariah. Tingkat kepatuhan bank syariah sangat erat kaitannya dengan perlindungan hukum terhadap konsumen (nasabah) secara tidak langsung, yaitu suatu perlindungan hukum yang diberikan kepada nasabah terhadap segala risiko kerugian yang timbul dari suatu kebijaksanaan atau timbul dari kegiatan usaha yang dilakukan oleh bank. Hal ini adalah upaya dan tindakan pencegahan yang bersifat internal oleh bank yang bersangkutan. ${ }^{11}$

Tingkat kepatuhan bank syariah dapat ditentukan dari kepatuhan bank dalam menerapkan prinsip kehati-hatian bank, sehingga berimplementasi kepada tingkat kesehatan bank yang merupakan hasil penilaian kuantitatif dan kualitatif atas berbagai aspek yang berpengaruh terhadap kondisi atau kinerja suatu bank. Menurut ketentuan Pasal 2 UU Perbankan Syariah menyatakan bahwa lembaga keuangan syariah dalam melakukan kegiatan usahanya berasaskan prinsip syariah, demokrasi ekonomi, dan prinsip kehati-hatian. Oleh karena itu prinsip kehati-hatian adalah salah satu terpenting yang wajib diterapkan oleh bank dalam menjalankan kegiatan usahanya. Bank harus selalu konsisten dalam melaksanakan peraturan perundang-undangan di bidang lembaga keuangan berdasarkan profesionalisme dan iktikad baik. Prinsip kehati-hatian tersebut meliputi kehati-hatian dalam melaksanakan peraturan

${ }^{31}$ Hermansyah, 146.

el-Qisț: Journal of Islamic Economics and Business (JIEB) 
perundang-undangan dalam kegiatan usaha bank, penerapan prinsip syariah dalam pemberian pembiayaan, dan menjaga kepercayaan nasabah terhadap bank syariah, sebagaimana terdapat dalam:

a. Pasal 51 UU Perbankan Syariah tentang kewajiban bank memelihara tingkat kesehatan bank dan melakukan kegiatan usaha dengan prinsip kehati-hatian.

b. Pasal 35 ayat (1) lembaga keuangan Syariah tentang penerapan prinsip kehati-hatian dalam penyaluran dana berdasarkan prinsip syariah. ${ }^{2}$

c. Pasal 38 ayat (1) dan Pasal 39 UU Perbankan Syariah tentang penyediaan informasi kemungkinan terjadimya risiko kerugian.

d.Pasal 36 UU Perbankan Syariah tentang kewajiban bank untuk menghindari kerugian dan menjaga kepentingan nasabah yang mempercayakan dananya.

Dalam mengoptimalkan pengawasan bank, bank juga mempunyai peranannya sendiri dalam pengaturan dan pengawasan dirinya dengan mengacu kepada peraturan dan ketentuan yang telah ditetapkan BI. Pengaturan dan pengawasan tersebut dikenal dengan self regulatory banking (SRB).33

${ }^{32}$ Hal tersebut berdasarkan UU Perbankan dan UU Perbankan Syariah yang secara rinci prinsip kehati-hatian perbankan secara teknis dapat dilihat dari ketaatan bank dalam melaksanakan ketentuan tentang: Modal inti bank umum; Kewajiban penyediaan modal minimum (KPMM); Posisi devisa neto (PDN); Batas pembiayaan bagi bank syariah dan UUS; Batas umum pemberian kredit (BMPK); Kualitas asset; Penyisihan penghapusan aset (PPA); Restrukturisasi kredit; Perstrusturisasi pembiayaan bagi bank syariah dan UUS; Giro wajib minimum (GWM); Tranparansi kondisi keuangan bank; Transparansi informasi produk bank dan penggunaan data pribadi nasabah, Prinsip kehati-hatian dalam kegiatan penyertaan modal bank umum; Prinsip kehati-hatian dalam aktivitas sekuritas aset bagi bank umum; Prinsip kehati-hatian dalam melaksanakan kegiatan Structured product bagi bank umum; Prinsip kehati-hatian dalam melaksanakan aktivitas keagenan produk keuangan luar negeri oleh bank umum; Prinsip kehati-hatian bagi bank umum yang melakukan penyerahan sebagai pelaksanaan pekerjaan kepada pihak lain; Penerapan strategi anti fraud bagi bank umum; Pedoman perhitungan ATMR menurut risiko untuk risiko kredit dengan menggunakan pendekatan standar; Kegiatan usaha dan jaringan kantor bank umum berdasarkan modal inti; Batasan Maksimum Pemberian Kredit (BMPK)/Legal Lending Limit); Kewajiban Mengumumkan Neraca; Perhitungan Laba Rugi; Manajemen Risiko. Departemen Perizinan dan Informasi Perbankan, 136-166.

33 Peraturan tentang SRB ini meliputi: (1) Pedoman penyusunan kebijakan perkreditan bank (PPKPB): Pasal 25 UU BI; Penilaian tingkat kesehatan bank di Indonesia dengan menggunakan metode CAMEL: PBI No. 6/10/PBI/2004; Pelaksanaan good corporate governance (GCG): SEBI No. 15/15/DPNP tanggal 29 April 2013; Satuan kerja audit intern (SKAI) bank umum: PBI No. 1/6/PBI/1999; Pelaksanaan fungsi kepatuhan bank umum: PBI No. 13/2/PBI 2011; Rencana bisnis bank: PBI No. 12/21/PBI/2010; Penerapan manajemen risiko dalam penggunaan teknologi informasi oleh bank umum: PBI No. 9/15/PBI/2007; Penerapan manajemen risiko bagi bank umum: PBI No. 5/8/PBI/2003; Penerapan menajemen risiko secara konsolidasi bagi bank yang melakukan pengendalian terhadap perusahaan anak: PBI No. 8/6/PBI/2006; Penerapan manajemen risiko pada internet banking: PBI No. 9/15/PBI/2007; Penerapan manajemen risiko pada bank yang melakukan aktivitas kerjasama pemasaran dengan perusahaan asuransi/bancassurance: SEBI No. 6/43/DPNP 7 Oktober 2004; Penerapan manajemen risiko pada aktivitas bank yang berkaitan dengan reksadana: SEBI No. 11/36/DPNP tanggal 14 Juni 2005; Sertifikat manajemen risiko bagi pengurus dan pejabat bank umum: PBI No. 11/19/PBI/2009; Penerapan manajemen risiko pada bank umum yang melakukan layanan nasabah prima (LNP): SEBI No. 13/29/DPNP tanggal 9 Desembewr 2011; Penerapan manajemen risiko pada bank yang melakukan aktivitas pemberian kerdit atau 
Ketentuan-ketentuan tersebut pada umumnya merupakan upaya untuk meningkatkan tingkat kesehatan bank yang secara khusus, apabila dianalisis, maka ketentuan yang bersifat prudential tersebut cukup menjamin dilaksanakannya prinsip kehati-hatian dalam penerapan prinsip syariah dalam operasi bank syariah seperti amanat UU Perbankan Syariah, ketentuan PBI No. 9/1/2007 tentang Sistem Penilaian Tingkat Kesehatan Bank Umum Berdasarkan Prinsip Syariah yang menentukan bahwa tingkat kesehatan bank syariah sekurang-kerangnya mencakup penilaian terhadap factor-faktor berikut:

a. Permodalan (capital);

b. $\quad$ Kualitas aset (Asset Quality);

c. Manajemen (management);

d. Rentabilitas (Earnings);

e. Likuiditas (Liquidity);

f. Solvabilitas;

g. Kualitas manajemen yang menggambarkan kapabilitas dalam aspek keuangan;

h. Kepatuhan terhadap prinsip syariah dan prinsip manajemen Islami.

Tetapi secara operasional, ketentuan-ketentuan tersebut belum menjamin diterapkannya prinsip syariah dalam kegiatan lembaga keuangan syariah, karena pengawasan terhadap kesyariahan produk dan akad dalam kegiatan penyaluran/pembiayaan syariah membutuhkan control yang sangat ekstra. Di sini bank syariah dalam upaya menghasilkan keuntungan (ma'ad) harus memperhatikan aspek sosial dan aspek riil dari penyalutan pembiayaan yang diberikan, termasuk tingkat kemaslahatannya. Maka, penulis berpendapat bahwa peraturan BI dan/atau OJK tentang prinsip kehati-hatian lembaga keuangan syariah belum mengakomodir prinsip kehati-hatian dalam penerapan prinsip syariah pada mekanisme akad dalam penyaluran pembiayaan sebagaimana diamanatkan oleh UU Perbankan Syariah, yaitu tingkat kesehatan dari aspek kepatuhan bank syariah terhadap prinsip syariah (khususnya kehatihatian bank dalam menghindari kegiatan-kegiatan yang dilarang). Di sinilah fungsi DSN-MUI dan para DPS-nya sangat dibutuhkan dalam mendukung perkembangan lembaga keuangan syariah.

Sebagai institusi keuangan syariah, penerapan prinsip syariah merupakan suatu keharusan yang tidak bisa diabaikan, karena kegiatan ekonomi institusi tersebut merupakan bagian dari sistem Islam yang memiliki hubungan yang erat kaitannya dengan aqidah dan syariah, tidak hanya berdimensi sosial, tetapi juga bernilai ibadah,34 sehingga dijiwai oleh nilai-nilai Islam.35 Sistem

pemilikan proterti, kredit atau pembiayaan konsumsi beragun property, dan kredit atau pembiayaan kendaraan bermotor: SEBi No. 15/40/DKMP tanggal 24 September 2013; Penerapan manajemen risiko pada bank syariah: PBI No. 13/23/PBI/2011; Penerapan program anti pencucian uang dan pencegahan pendanaan terorisme (Program APU dan PPT): PBI No. 14/27/PBI/2012; Penyelesaian pengaduan nasabah: PBI No. 7/7/PBI/2005 sebagaimana telah diubah dengan PBI No. 10/10/2008; Ketentuan produk pembiayaan kepemilikan emas (PKE) bagi bank syariah dan UUS: SEBI No. 14/16/DPbS 31 Mei 2012. Departemen Perizinan dan Informasi Perbankan, 174-197.

34 Nurul Huda dan Mohammad Haykal, Lembaga Keuangan Islam, Tinjauan Teoritis dan Prakris, (Jakarta: Kencana Prenada Media Grup, 2010), 2 
ekonomi syariah pada dasarnya terbentuk dari empat landasan dasar: ketuhanan (ilahiyah), keadilan dan keseimbangan, kebebasan, dan pertanggungjawaban. ${ }^{36}$ Dari landasan dasar tersebut terbentuklah satu kesatuan sistem ekonomi yang terdiri atas sektor keuangan, sektor riil, dan sektor sosial. Ketiga sektor tersebut tercermin dalam:

a. Kegiatan ekonomi (mencari materi/harta) merupakan tuntutan kehidupan yang harus dipenuhi manusia, maka manusia dituntut untuk berusaha dan bekerja keras dengan cara yang halal. $37 \mathrm{Hal}$ ini berimplikasi bahwa Allah memberikan kebebasan individual kepada manusia untuk beraktivitas di bidang ekonomi sejauh masih selaras dengan ketentuan syariat Islam. ${ }^{38}$

b. Kegiatan ekonomi dalam Islam memiliki prinsip keseimbangan, di mana meletakkan kepentingan dunia-akhirat, material-spiritual, individu-sosial pada proporsial yang sama. 39

c. Sistem ekonomi Islam tidak memandang kekayaan Negara berdasarkan pada jumlah uang (financial), tetapi ditentukan oleh tingkat produksi dan Neraca pembayaran uang positif. Sehingga factor produksi menjadi factor penggerak pembangunan, menyerap tenaga kerja, meningkatkan pendapatan Negara. Hal ini menyiratkan bahwa sistem ekonomi Islam sangat bergantung pada sektor riil di masyarakat. 40

Dalam lembaga keuangan syariah ketiga komponen tersebut direalisasikan ke dalam produk-produk dan jasa keuangan yang diberikan oleh bank syariah, di mana setiap akad yang digunakan harus terbebas dari unsur-unsur yang dilarang, seperti riba, gharar, maisir, iktinaz, ihtikar, dan kegiatan lainnya yang diharamkan. Prinsip dan karakteristik inilah yang menjadikan bank syariah sebagai antitesa terhadap sistem lembaga keuangan dengan sistem prinsip bunga yang nyaris gagal. ${ }^{41}$ Maka dapat dikatakan bahwa prinsip-prinsip syariah inilah yang seharusnya diawasi oleh lembaga otoritas, selain peraturan lembaga keuangan yang bersifat umum.

35 Umar Chapra mengatakan bahwa sistem dalam ekonomi Islam merupakan suatu konsep yang sepadan antara dua unsur, kekayaan di dunia yang merupakan hak mutlak Allah dan kepada manusia diamanahkan segala yang ada di bumi untuk diproses atas dasar khilafah yang dapat disimpulkan: (a) kesejahteraan ekonomi dalam kerangka norma-norma moral Islam; (b) persaudaraan dan keadilan menyeluruh; (c) pemberian pendapatan yang adil; (d) kebebasan individu dalam konteks kepentingan sosial. Syukri Iska, 125-126

${ }^{36}$ Abdul Manan, Hukum Ekonomi Syariah Dalam Perspektif Kewenangan Peradilan Agama, (Jakarta: Kencana Prenada Media Grup, 2012), 34.

37 Seperti dalam QS. al-A'raf: 10; an-Naba': 11 dan hadits nabi yang berarti: "Berusahalah untuk memeroleh kehidupan dengan cara yang halal, merupakan suatu kewajiban sesudah kewajiban sembahyang." Suhrawardi K. Lubis dan Farid Wajdi, Hukum Ekonomi Islam, (Jakarta: Sinar Grafita, 2012), 2-3.

${ }^{38}$ Syukri Iska, 3.

39 Abdul manan, 24-25.

40 Ibid, 22

${ }^{41}$ Di Indonesia, perkembangan ekonomi Islam di awali dengan berdirinya bank syariah di Indonesia pada tahun 1992 yaitu Bank Muamalat, dan terus berkembang setelah terjadinya krisis ekonomi dan moneter tahun 1997/1998 yang lalu. Suhrawardi K. Lubis dan Farid Wajdi, 4 . 
DSN-MUI sebagai otoritas syariah di sektor jasa keuangan pada kenyataannya, hanya mempunyai hak untuk menetapkan fatwa yang oleh BI dan Menteri Keuangan ditetapkan sebagai mitra dalam mengatur dan mengawasi LKS di Indonesia. Apabila terjadi suatu pelanggaran yang dilakukan oleh LKS, khususnya yang berkaitan dengan pelanggaran terhadap prinsip syariah DSN-MUI tidak mempunyai peran yang berarti. Dampak hukum dari pelanggaran tersebut adalah sanksi yang hanya diberikan oleh OJK,42 sebagaimana diatur dalam UU Perbankan Syariah:

Bank Indonesia menetapkan sanksi administratif kepada

Bank Syariah atau UUS, anggota dewan komisaris, anggota Dewan Pengawas Syariah, direksi, dan/atau pegawai Bank Syariah atau Bank Umum Konvensional yang memiliki UUS, yang menghalangi dan/atau tidak melaksanakan Prinsip Syariah dalam menjalankan usaha atau tugasnya atau tidak memenuhi kewajibannya sebagaimana ditentukan dalam Undang-Undang ini.

Ketentuan tersebut menimbulkan celah dalam upaya pengoptimalkan pengawasan lembaga keuangan syariah, di mana apabila terjadi penyelewengan fatwa oleh lembaga keuangan syariah, tidak ada penanganan langsung yang bisa mencegah terjadinya kerugian pada nasabah seperti kasus PT Golden Tranders Indonesia Syariah (GTIS).43 Walaupun dalam struktur keorganisasian, OJK memiliki direktorat khusus yang menangani masalah seputar lembaga keuangan syariah,44 tetapi diterapkannya akad sesuai fatwa tidak dapat diawasi dengan optimal karena fatwa tersebut bukan produk OJK, melainkan DSN-MUI yang terpisah secara structural dari OJK. Sehingga penyelewengan terhadap fatwa tidak dapat ditanggulangi secara dini oleh OJK. Selain itu, karena DSN-

42 Apabila pelanggaran tersebut mengakibatkan kerugian pihak lain maka dapat dikenakan sanksi pidana, sebagaimana diatur dalam Pasal 63 sampai dengan Pasal 65 Perbankan Syariah. 43 Kasus ini muncul kepermukaan karena adanya aduan dari para nasabah yang tidak mendapatkan janji keuntungan untuk beberapa bulan dan diduga pendiri PT ini membawa kabur dana nasabah perusahaan ini. Kasus investasi emas yang dilakukan oleh PT GTIS adalah akad murabahah yang digunakan secara prinsip tidak memenuhi kriteria akad murabahah dan mudharabah sesuai syariah (fatwa DSN-MUI). GTIS menjual emas dengan ketentuan harga emas lebih besar dari harga emas di pasar, yaitu sekitar 30-40\% dari harga pasar dengan asumsi bahwa harga emas akan terus naik, dan penetapan bonus yang diperjanjikan oleh pihak GTIS diawal dengan presentase tetap tidak terdapat dalam ketentuan akad murabahah dalam jual beli. Selain itu jenis usaha bagi hasil juga tidak jelas, sehingga keuntungan yang diberikan kepada nasabah setiap bulannya merupakan bonus yang ditetapkan di awal. Masalah yang paling krusial dalam kasus ini adalah penyalah-gunaan sertifikat MUI yang diberikan kepada GTIS. Sertifikat tersebut diberikan untuk akad jual beli, di mana nasabah mendapatkan bonus karena adanya proses jual beli dengan perjanjian membeli kembali (buy back) dalam waktu tertentu (seperti fatwa DSN-MUI No), bukan setifikat investasi emas yang diklaim pihak GTIS. Demikian penjelasan Ketua MUI K Ma'ruf Amin dalam wawancara dengan majalah detik edisi 67. Diakses dari

http://ekonomi.kompasiana.com/moneter/2013/03/17/kelirumologi-investasi-emas-gtis537972.html pada 10/29/2013 10:49 am.

44 Yang dibawahi oleh Seorang Direktur Pengaturan, Pengembangan, Perizinan, dan Pengawasan Perbankan Syariah yang sekarang dipimpin oleh Ahmad Buchori. Struktur Organisasi Otoritas Jasa Keuangan (OJK) wide, diakses dari www.ojk.go.id/dl.php?i=286 pada 3/31/2015 11:44 am. 
MUI bukan lembaga otoritas yang dapat mengatur LKS secara langsung, fatwa DSN-MUI juga tidak secara otomatis mengikat setiap LKS sebelum dijadikan regulasi oleh OJK. Sehingga tidak semua fatwa tersebut dapat diserap oleh OJK karena tidak bisa diterapkan dalam bahasa peraturan perundang-undangan. 45

Walaupun DSN-MUI diberi hak untuk memastikan bahwa fatwa yang ditetapkan dapat diserap ke dalam operasional lembaga keuangan syariah melalui DPS, tetapi DPS tidak memiliki hak untuk bertindak apabila dalam operasional bank syariah tidak mematuhi fatwa yang telah ditetapkan DSNMUI. Di sini DPS hanya sebagai pemeriksa dan pemberi informasi kepada otoritas dalam penanganan pelanggaran bank syariah tersebut. Hal tersebut diperburuk juga oleh kesan bahwa DPS dibiayai oleh bank yang diawasinya. 46 Hal tersebut tentu sedikit banyak mempengaruhi kinerja dan pengoptimalisasian peran DSN-MUI dalam pengawasan lembaga keuangan syariah.

Berdirinya OJK sebagai lembaga otoritas di sektor jasa keuangan memberikan peluang dalam peningkatan sistem pengaturan dan pengawasan lembaga keuangan syariah. Kinerja regulasi dari sisi regulasi lembaga keuangan syariah yang sebelumnya di bawah pengawasan BI dapat dikatakan sangat baik. Hal tersebut terbukti dari banyaknya peraturan BI yang mengatur tentang lembaga keuangan syariah serta usaha BI dalam merumuskan sebuah Grand Strategi Pengembangan Lembaga keuangan Syariah sebagai strategi komprehensif pengembangan pasar dan pembentukan citra baru lembaga keuangan syariah nasional yang bersifat inklusif dan universal.47 $\mathrm{Hal}$ ini tentunya menggambarkan bahwa perkembangan industri lembaga keuangan syariah yang pesat dilakukan dalam kerangka kehati-hatian yang mencukupi. Dan OJK sebagai lembaga ototritas yang baru dituntut untuk lebih optimal dalam pengawasan lembaga keuangan syariah.48 Walaupun demikian, penempatan supervise dan regulasi sistem keuangan syariah dapat juga menyebabkan OJK kehilangan focus yang pada akhirnya memupuskan momentum perkembangan yang pada saat ini sedang diraih. Untuk menghindari hal tersebut, perkembangan sistem keuangan syariah harus didukung secara struktural dan fungsional dalam OJK. Salah satunya adalah pengoptimalan peran DPS di setiap LKS. Tugas DSP sebagaimana telah diatur dalam UU Perbankan Syariah Pasal 33 ayat (3)49 belum memberikan ruang yang cukup bagi DPS untuk bertugas. Selain itu, terikatnya DPS sebagai pihak yang dibiayai oleh bank yang diawasinya juga menjadi suatu masalah yang cukup mempengaruhi kinerja DPS. Oleh karena itulah perlu dilakukan kembali

\footnotetext{
45 M. Cholil Nafis, 108.

${ }^{46}$ Walaupun DPS merupakan pihak yang independen dan tidak berada di bawah pimpinan bank yang diawasi, tetapi setiap anggota DPS menerima uang transportasi yang dibebankan kepada lembaga keuangan syaria M. Cholil Nafis, 100.

47 http://www.bi.go.id/id/perbankan/syariah/Contents/Default.aspx 12/22/2013 11:29 am.

48 Terbentuknya OJK dapat dipandang sebagai suatu peluang bagi sistem keuangan syariah untuk lebih dapat mengarahkan perkembangan industri secara lintas sektoral dimana sistem keuangan syariah secara keseluruhan akan dapat mencapai tingkat efisiensi operasi yang lebih tinggi. Hermansyah, 214

49 Yaitu memberikan nasihat dan saran kepada direksi dan mengawasi kegiatan bank agar sesuai dengan prinsip syariah.
} 
struktur pengorganisasian lembaga-lembaga pengatur dan pengawas di lembaga keuangan syariah agar dicapai mekanisme koordinasi yang lebih efektif dalam menangani masalah-masalah lembaga keuangan syariah, yaitu lembaga otoritas syariah yang dapat menutupi kelemahan DSN-MUI dan DPS selama ini.

OJK sebagai lembaga otoritas di sektor jasa keuangan yang baru, sudah semestinya memiliki kapabilitas yang tinggi dalam pengembangan sektor jasa keuangan syariah, mengingat bahwa lembaga keuangan syariah di Indonesia memiliki potensi yang sangat besar, meskipun pangsa pasar lembaga keuangan syariah masih sangat kecil jika dibandingkan dengan bank konvesional, yaitu sekitar 5\%.50 Adalah baik apabila peran DSN dan DPS dalam pengaturan dan pengawasa LKS diperluas, seperti hak dalam mereview produk-produk syariah yang telah beredar dan berhak memutuskan apakah produk tersebut bisa dilanjutkan untuk dipasarkan atau dihentikan pemasarannya disebabkan oleh ketidak sesuaiannya terhadap syariah. Sehingga tidak terjadi lagi kasus seperti GTIS penting untuk ditekankan bahwa peran DSN dan DPS bukan hanya berorientasi kepada penetapan fatwa belaka, tetapi mempunyai hak-hak yang tegas dalam hal pengawasan lembaga keuangan syariah dalam kepatuhannya terhadap penerapan prinsip syariah yang diinterpretasikan ke dalam fatwafatwa tersebut. Hal ini tidak akan terwujud kecuali DSN-MUI menjadi bagian yang terstruktur dalam kepengurusan OJK.

\section{PENUTUP}

Berdasarkan uraian analisis di atas, maka penulis menyimpulkan bahwa DSN MUI sebagai lembaga yang didirikan untuk memberikan ketentuan hukum Islam kepada LKS dalam menjalanan aktivitasnya. Kedudukan DSN-MUI sebagai lembaga yang terlepas dari lembaga otoritas di sektor jasa keuangan, khususnya dalam upaya pengoptimalisasian lembaga keuangan syariah memiliki beberapa kelemahan, yaitu: terdapat ketidaksepahaman antara lembaga otoritas dengan DSN dalam memahami masalah di sektor jasa keuangan syariah, terdapat fatwa yang tidak dapat diserap dalam bahasa peraturan perundang-undangan, adanya pelanggaran prinsip syariah seperti praktek gadai emas yang menyimpang dari fatwa DSN, terikatnya DSP dengan bank yang diawasi dengan adanya biaya transportasi yang menjadi beban bank syariah terkait, serta tidak mengikatnya fatwa DSN secara langsung terhadap bank-bank syariah, di mana fatwa DSN tersebut baru mengikat apabila telah diakomodasikan ke dalam peraturan perundang-undangan. Kelemahankelemahan tersebut tentu dapat memperburuk kinerja LKS yang ada, sehingga pengintegralisasian DSN-MUI ke dalam Struktur kepengurusan OJK merupakan suatu keniscayaan untuk mengoptimalkan pengawasan LKS agar sesuai dengan prinsip-prinsip syariah.

\footnotetext{
${ }^{50}$ Hingga Oktober 2013 pangsa pasar perbankan syariah mencapai 4,8 \% dengan rekening di perbankan syariah sebanyak 12 juta atau 9,2 \% dari total perbankan nasional dengan 2.925 kantor, lihat http://www.metrotvnews.com/metronews/read/2013/12/16/ 22/12/2013 1:00 pm.
} 


\section{DAFTAR PUSTAKA}

Ali, Zainuddin. Metode Penelitian Hukum. Jakarta: Sinar Grafika. 2011.

Antonio, Muhammad Syafi'ie. Bank Syariah Dari Teori ke Praktik. Jakarta: Gema Insani Press. 2007.

Ascarya. Akad dan Produk Bank Syariah. Jakarta: Rajawali Press. 2013.

Departemen Perizinan dan Informasi Perbankan. Booklet Perbankan Indonesia 2013. Jakarta:BI. 2013.

Hermansyah. Hukum Perbankan Nasional Indonesia. Jakarta: Kencana Prenada Media Grup. 2011.

Huda, Nurul dan Mohammad Haykal. Lembaga Keuangan Islam, Tinjauan Teoritis dan Prakris. Jakarta: Kencana Prenada Media Grup. 2010.

Iska, Syukri. Sistem Perbankan Syariah di Indonesia Dalam Perspektif Fikih Ekonomi. Yogyakarta: Fajar Media Press. 2012.

Lubis, Suhrawardi K. dan Farid Wajdi. Hukum Ekonomi Islam. Jakarta: Sinar Grafika. 2012.

Nafis, M. Cholil. Teori Hukum Ekonomi Syariah. Jakarta: UI-Press. 2011.

Manan, Abdul. HukumEkonomi Syariah Dalam Perspektif Kewenangan Peradilan Agama. Jakarta: Kencana Prenada Media Grup. 2012.

Soekanto, Soerjono dan Mamudji, Sri. Penelitian Hukum Normatif. Jakarta: Raja Grafindo Persada. 2007.

Sumitro, Warkum. Asas-Asas Perbankan Syariah dan Lembaga-lembaga Terkait. Jakarta: Raja Grafindo Persada. 2004.

\section{Artikel dan Jurnal}

Masciandaro, Donato dan Quintyn, Marc."Reforming Financial Supervision and the Role of Central Banks: a Review of Global Trends, Causes and Effects (1998-2008)," Centre of Economic Policy Research. Februari 2009.

Song, Inwong dan Oosthuizen, Carel. "Islamic Banking Regulation and Supervision: Survey Result and Challenges," IMF Paper. Desember 2014.

\section{Internet}

BI. Arsitektur Perbankan Indonesia dari http://www.bi.go.id/web/id/ diunduh 10/30/2013

http://www.bi.go.id/id/perbankan/syariah/Contents/Default.aspx 12/22/2013

http://www.metrotvnews.com/metronews/read/2013/12/16/ diunduh $22 / 12 / 2013$

Ma'ruf Amin dalam wawancara dengan majalah detik edisi 67, dari http://ekonomi.kompasiana.com/moneter/2013/o3/17/kelirumologiinvestasi-emas-gtis-537972.html diunduh 10/29/2013

Struktur Organisasi Otoritas Jasa Keuangan (OJK) wide, dari www.ojk.go.id/dl.php?i=286 diunduh 3/31/2015

\section{Peraturan Perundang-Undangan}

Undang-Undang No. 21 Tahun 2008 tentang Lembaga keuangan Syariah Undang-Undang No. 21 Tahun 2011 tentang Otoritas Jasa keuangan (OJK) PBI No. 13/2/PBI/2-11 tentang Pelaksanaan Fungsi Kepatuhan Bank Umum 